\title{
Molecular Mechanisms Contributing to Long-Lasting Synaptic Plasticity at the Temporoammonic-CA1 Synapse
}

\author{
Miguel Remondes and Erin M. Schuman ${ }^{1}$ \\ Caltech/HHMI, Division of Biology, Pasadena, California 91125, USA
}

\begin{abstract}
The hippocampus and the nearby medial temporal lobe structures are required for the formation, consolidation, and retrieval of episodic memories. Sensory information enters the hippocampus via two inputs from entorhinal cortex (EC): One input (perforant path) makes synapses on the dendrites of dentate granule cells as the first set of synapses in the trisynaptic circuit, the other (temporoammonic; TA) makes synapses on the distal dendrites of CAl neurons. Here we demonstrate that TA-CAl synapses undergo both early- and late-phase long-term potentiation (LTP) in rat hippocampal slices. LTP at TA-CAl synapses requires both NMDA receptor and voltage-gated $\mathrm{Ca}^{2+}$ channel activity. Furthermore, TA-CAl LTP is insensitive to the blockade of fast inhibitory transmission (GABA $A_{A}$-mediated) and, interestingly, is dependent on $G A B A_{B}$-dependent slow inhibitory transmission. These findings indicate that the TA-CAl synapses may rely on a refined modulation of inhibition to exhibit LTP.
\end{abstract}

The hippocampus and its associated medial temporal lobe structures are required for the formation, consolidation, and retrieval of episodic memories (Morris et al. 1982; Squire and Zola 1997; Eichenbaum 2000; Scoville and Milner 2000). Sensory information enters the hippocampus via two inputs from entorhinal cortex (EC). The first input comprises the axons of layer II EC neurons that terminate on the dendrites of the dentate granule cells. This input is then processed serially via two additional sets of synapses in the hippocampal subfields, CA3 and CA1 (Cajal 1968; Witter et al. 1989). Together, these three sets of synapses constitute the trisynaptic pathway. The second input comprises the axons of layer III EC neurons that terminate directly on the distal dendrites of CA1 neurons and interneurons in stratum lacunosum moleculare (SLM; Fig. 1A). This bundle of axons is accompanied by a projection from layer II EC neurons to CA3 neurons (Hjorth-Simonsen and Jeune 1972; Steward 1976; Steward and Scoville 1976); together, this cortico-hippocampal input is often called the temporoammonic path (TA; Lorente de No 1934) or the direct entorhinal projection.

Of the two EC inputs, the trisynaptic pathway has received the most attention to date in experimental and theoretical studies of hippocampal function. There are behavioral and physiological studies, however, that suggest an important role for the TA pathway in hippocampal function. For example, behavioral experiments in primates have shown that SLM-the target of the TA pathway-exhibits a specific rise in metabolic activity upon the completion of sensorimotor and cognitive tasks (Friedman and Goldman-Rakic 1988; Sybirska et al. 2000). In addition, destruction of the CA3 input to CA1 in rats leaves some properties of CA1 principal cells intact (Mizumori et al. 1989), including their place selectivity (Brun et al. 2002). Similarly, animals with extensive CA3 lesions still perform well on spatial recognition tasks (Brun et al. 2002).

A few studies have examined the pharmacology (Colbert and Levy 1992), physiology (Doller and Weight 1982; Yeckel and

\footnotetext{
'Corresponding author.

E-MAIL schumane@its.caltech.edu; FAX (626) 568-0631.

Article and publication are at http://www.learnmem.org/cgi/doi/10.1101/ Im.59103.
}

Berger 1990; Empson and Heinemann 1995; Leung et al. 1995), and the plasticity of the TA pathway (Doller and Weight 1985; Colbert and Levy 1993; Dvorak-Carbone and Schuman 1999a). Recently, the pharmacology of plasticity at the perforant pathway to CA3 region has been studied in vivo; the synapses originating at the lateral component of this pathway exhibit NMDAreceptor-independent LTP, whereas synapses originating medially exhibit NMDA-receptor-dependent LTP (Do et al. 2002).

A prevalent view has been that, because of a powerful inhibitory component, the TA pathway cannot exhibit long-term potentiation (LTP) unless $\mathrm{GABA}_{\mathrm{A}}$-mediated inhibition is blocked (Colbert and Levy 1993; Golding et al. 2002). The inability of the TA pathway to exhibit LTP with inhibitory transmission intact may have eclipsed considerations that it can act as a long-term information encoder in the hippocampal circuit, and thus participate in learning and memory. Recently, however, both LTD (Dvorak-Carbone and Schuman 1999a) and LTP have been described in the naive hippocampal slice (Remondes and Schuman 2002). A previous study (Doller and Weight 1985) also showed potentiation of the population spike.

Here we demonstrate that TA-CA1 synapses undergo both early- and late-phase LTP (up to $8 \mathrm{~h}$ ) in rat hippocampal slices. LTP at TA-CA1 synapses requires NMDA receptors and voltagegated $\mathrm{Ca}^{+}$channels, is insensitive to the blockade of fast inhibitory transmission $\left(\mathrm{GABA}_{\mathrm{A}}\right.$-mediated; Chapman et al. 1998), and, interestingly, depends on $\mathrm{GABA}_{\mathrm{B}}$-dependent slow inhibitory transmission.

\section{RESULTS}

\section{The TA Pathway Exhibits NMDA \\ Receptor-Dependent LTP}

Some studies have suggested that the TA-CA1 synapses only exhibit LTP when $\mathrm{GABA}_{\mathrm{A}}$ receptors are blocked (Colbert and Levy 1993; Golding et al. 2002). Recently, however, LTP has been observed at TA-CA1 synapses following four trains of high-frequency stimulation (HFS) with synaptic inhibition intact (Remondes and Schuman 2002). Here, the ability of TA-CA1 synapses to exhibit LTP following theta burst stimulation (TBS) was 


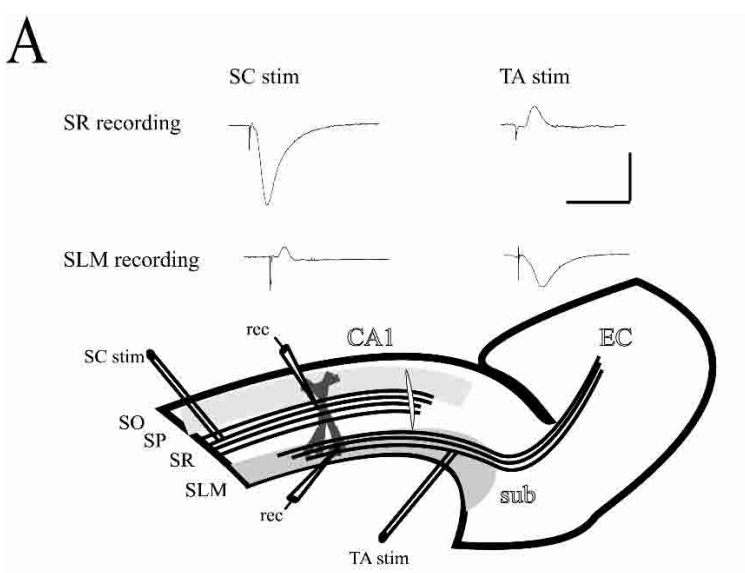

B

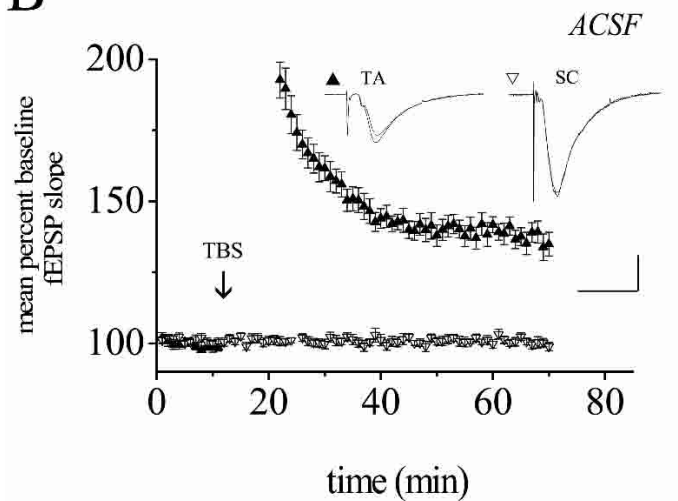

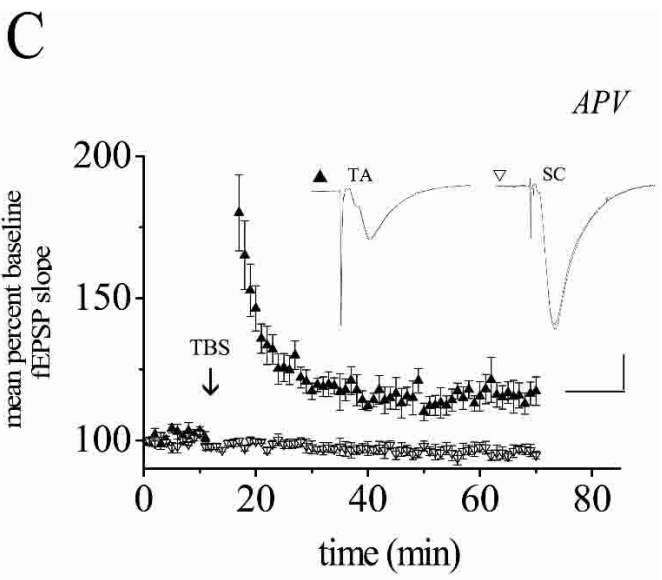

$\mathrm{D}$

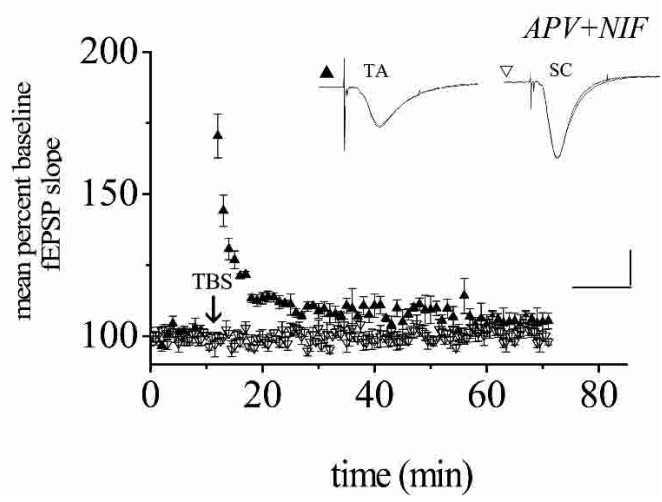

Figure 1 TA-CA1 synapses exhibit TBS-induced LTP. ( $A$, top) Representative field potentials showing the following: negative-going fields in SR in response to SC stimulation and in SLM in response to TA stimulation, and positive-going fields in SR in response to TA stimulation and in SLM in response to SC stimulation. (Bottom) Scheme of recording setup showing the position of stimulating and recording electrodes in stratum radiatum (SR) and stratum lacunosum moleculare (SLM). The scale bar for all panels, $0.5 \mathrm{mV}, 20 \mathrm{msec}$. (B) Ensemble average of all TA LTP experiments. LTP was elicited by TBS, which resulted in significant potentiation of TA-CA1 synaptic transmission without affecting the simultaneously recorded SC-CA1 synaptic responses. (C) Ensemble average of all TA-LTP experiments conducted in the presence of the NMDA receptor antagonist, APV (50 $\mu M$ ); APV significantly decreased the magnitude of LTP. In this and all figures, traces shown are for 10 min before (black) and 60 min after LTP induction . (D) Ensemble average of all TA-LTP experiments conducted in the presence of AP5 and the voltage-gated $\mathrm{Ca}^{2+}$ channel antagonist nifedipine $(50 \mu \mathrm{M})$; the combination of APV and nifedipine prevented LTP. In $B-D$, the first few responses following the TBS are not shown in order to exhibit an expanded $Y$-scale for the remainder of the experiment.

reexamined. Field excitatory postsynaptic potentials (fEPSPs) that reflect the isolated TA-CA1 and SC-CA1 synaptic responses (Dvorak-Carbone and Schuman 1999a; Remondes and Schuman 2002) were recorded (Fig. 1A). Theta burst stimulation was applied to the TA path of naive slices (with synaptic inhibition intact). TBS resulted in a long-lasting potentiation of synaptic transmission at TA-CA1 synapses (mean percent of baseline 60 min following TBS, TA: $133.0 \% \pm 4.0 \%, n=8$ slices, from 5 rats; Fig. 1B), whereas the simultaneously recorded Schaffer collateral - CA1 responses were unaltered by TA TBS (mean percent of baseline, SC: $100.3 \% \pm 1.6 \%, n=8$ ). These results indicate that TA-CA1 synapses can undergo LTP by either TBS or HFS (Remondes and Schuman 2002) with synaptic inhibition intact.

Many forms of synaptic plasticity require the activity of NMDA receptors (Collingridge 1987). The excitatory TA-CA1 synapses possess both AMPA and NMDA receptors (data not shown); NMDA receptor antagonists reduce HFS-induced LTP (Remondes and Schuman 2002) or LTD at TA-CA1 synapses (Dvorak-Carbone and Schuman 1999a). Similarly, an NMDA receptor antagonist reduced LTP induced by TBS (Fig. 2; mean percent of baseline, TA: $116.1 \% \pm 4.7 \%$; SC: $95.8 \% \pm 1.9 \% ; n=7$ slices, from 4 rats). Because there was a small amount of residual
TBS-induced potentiation in the presence of an NMDA-receptor antagonist (APV), the potential contribution of L-type $\mathrm{Ca}^{2+}$ channels was also examined. The joint application of APV and the L-type $\mathrm{Ca}^{2+}$ antagonist nifedipine completely prevented TBS-induced LTP (mean percent of baseline, TA: $106.1 \% \pm 3.7 \%$; SC: $100.7 \% \pm 2.2 \%, n=4$ slices, from 3 rats). A similar dependence on both NMDA- and $\mathrm{Ca}^{2+}$ channels was recently reported by Golding et al. (2002) in examining TA-LTP induced in the presence of $\mathrm{GABA}_{\mathrm{A}}$ receptor antagonists.

\section{Early TA-LTP Requires $\mathrm{GABA}_{\mathrm{B}}$-Dependent Inhibition}

Intracellular recordings from CA1 neurons have shown that TA stimulation elicits a substantial inhibitory postsynaptic potential (IPSP), presumably by activating SLM border interneurons and possibly (although less likely) SOA interneurons (Andersen et al. 1969, 1980; Empson and Heinemann 1995; Dvorak-Carbone and Schuman 1999b). In addition, burst stimulation similar to that used to elicit LTP can result in summation of the TA-elicited IPSP (Dvorak-Carbone and Schuman 1999b). Thus, the sensitivity of TA-CA1 LTP to manipulations of inhibitory transmission was examined. Inhibition of $\mathrm{GABA}_{\mathrm{B}}(\mathrm{CGP} ; 1000 \mu \mathrm{M})$, but not $\mathrm{GABA}_{\mathrm{A}}$

\section{Learning \& Memory}

www.learnmem.org 
A

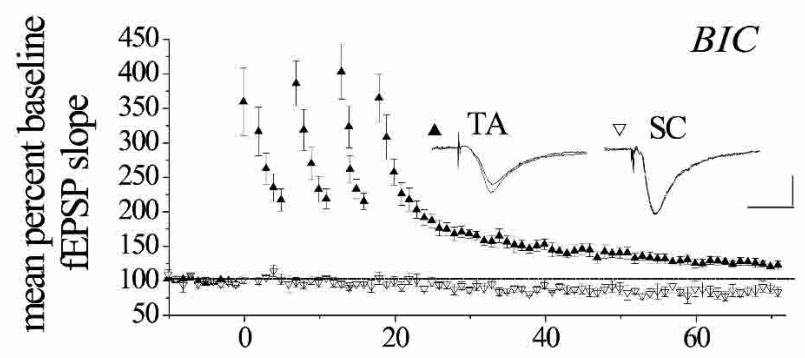

B

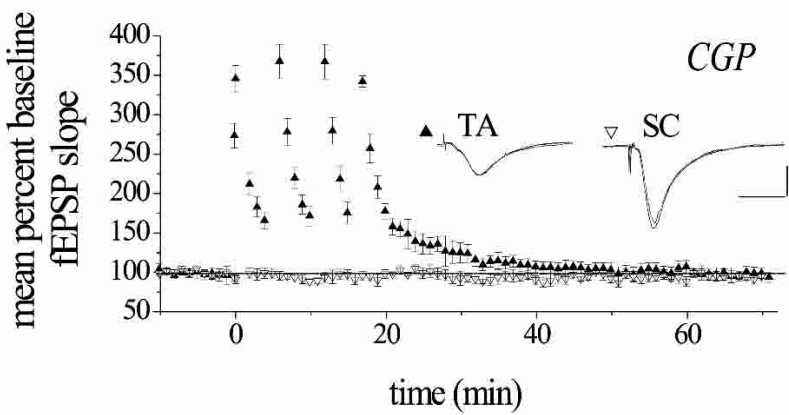

C

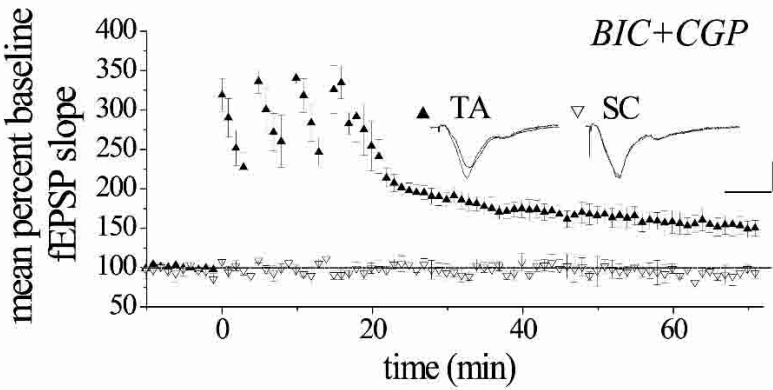

D

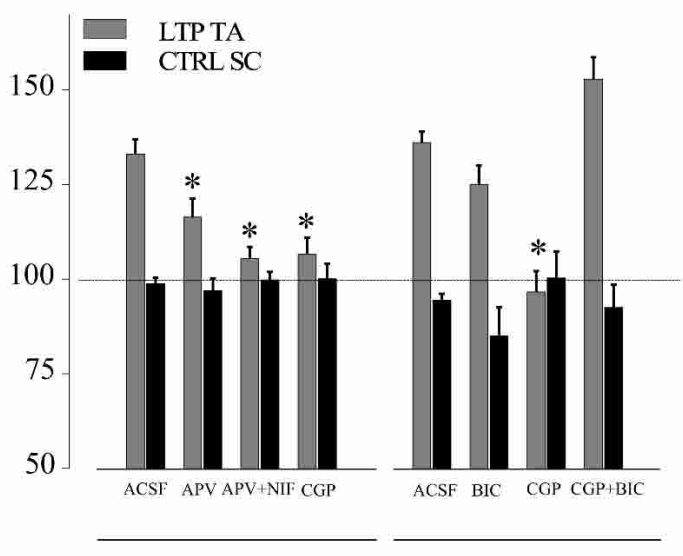

TBS

\section{HFS}

Figure 2 TA-CA1 LTP is sensitive to a GABA receptor antagonist. ( $A$ ) Ensemble average of all TA-CA1 experiments conducted in the presence of the $\mathrm{GABA}_{\mathrm{A}}$ receptor antagonist bicuculline; LTP was not affected by bicuculline. The scale bar for all panels, $0.5 \mathrm{mV}, 20 \mathrm{msec}$. ( $B$ ) Ensemble average of all TA-CA1 experiments conducted in the presence of the $G A B A_{B}$ receptor antagonist, CGP; LTP was significantly inhibited by CGP. (C) Ensemble average of all TA-CA1 experiments conducted in the presence of both a GABA and a GABA $A_{B}$ receptor antagonist. As predicted, CGP no longer inhibited LTP. the combination of inhibitors increased the magnitude of LTP. (D) Summary graph showing the magnitude of potentiation observed in TBS and HFS early-LTP experiments. Asterisks indicate groups that differed significantly from the TA-LTP group in ACSF as determined by an ANOVA.

receptors (bicuculline; $20 \mu \mathrm{M}$ ), prevented HFS-induced TA-LTP (Fig. 2; mean percent of baseline, CGP: $96.6 \% \pm 5.5 \%, n=6$ slices, from 4 rats; bicuc: $125.0 \% \pm 4.9 \%, n=7$ slices, from 3 rats). CGP also blocked TBS-induced potentiation at the TA-CA1 synapse (mean percent of baseline, CGP: $106.6 \% \pm 4.4 \%, n=3$ slices, from 2 rats). This finding is similar to that observed at both perforant-path-dentate granule cell synapses (Mott and Lewis 1992) and Schaffer-collateral-CA1 neuron synapses (Davies et al. 1991) and may reflect the need for $\mathrm{GABA}_{\mathrm{B}}$-receptor-mediated disinhibition, which normally facilitates LTP induction. Voltageclamp recordings of the monosynaptic IPSP (elicited by Schaffer collateral stimulation) show a consistent paired pulse depression of inhibition, sensitive to the application of CGP35348 (Davies et al. 1991). This result, together with the LTP inhibition observed under $\mathrm{GABA}_{\mathrm{B}}$ blockade, strongly indicates that repetitive stimulation of interneurons leads to a presynaptic GABAb activation, responsible for a depression of sustained GABA release (Davies et al. 1991; Mott and Lewis 1992). If this idea is correct, then blocking $\mathrm{GABA}_{\mathrm{A}}$-receptor-mediated inhibition should prevent the block of TA-LTP by the GABA ${ }_{B}$ receptor antagonist. Indeed, this was the case, coapplication of bicuculline and CGP clearly did not inhibit TA-LTP. On the contrary, TA-LTP was robust under these conditions (mean percent of baseline $60 \mathrm{~min}$ posttetanus $=152.9 \% \pm 1.2 \%, n=3$ slices, from 3 rats). The enhancement of LTP under complete GABA receptor blockade is likely due to an augmented postsynaptic depolarization during the
TBS, owing to the absence of the usual (opposing) hyperpolarization imposed by $\mathrm{GABA}_{\mathrm{A}}$ receptor activation.

\section{TA-CA1 Synapses Exhibit Protein Synthesis-Dependent Late-Phase LTP}

The enhancement of synaptic transmission observed in vitro can endure for minutes to hours. LTP is often divided into early- and late-phase potentiation, the hallmark of the latter being its dependence on protein synthesis. We also examined whether TA-CA1 synapses exhibit LTP that is enduring. Like Schaffer collateral-CA1 synapses (e.g., Frey and Morris 1997), TA-CA1 synapses readily exhibit late-phase LTP (L-LTP; Fig. 3). In the experiment shown in Figure 3A, synaptic transmission remained significantly enhanced for $8 \mathrm{~h}$ following the inducing stimulus. In all experiments, the LTP measured at $3 \mathrm{~h}$ was of a similar magnitude to that observed at $60 \mathrm{~min}$ (Fig. 3; mean percent of baseline 215 min posttetanus $=149.9 \% \pm 4.2 \% ; n=4$ slices, from 4 rats). At Schaffer-collateral-CA1 synapses, both late-phase LTP (Stanton and Sarvey 1984; Frey et al. 1988; Otani and Abraham 1989; Nguyen et al. 1994; Kang et al. 1997) and LTD (Kauderer and Kandel 2000) require protein synthesis. Similarly, the L-LTP at the TA-CA1 synapses was inhibited by anisomycin (40 $\mu \mathrm{M}$; Fig. 3; mean percent of baseline 215 min posttetanus $=114.2 \% \pm 2.1 \% ; n=4$ slices, from 4 rats). In separate experiments, we examined the effects of anisomycin alone (with- 
A

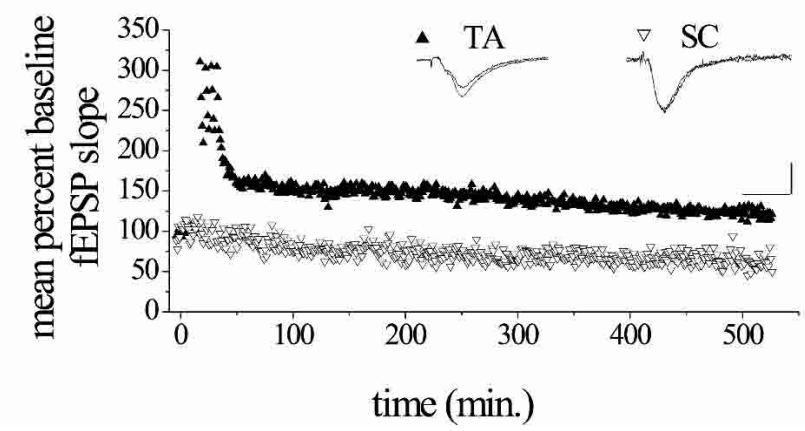

$\mathrm{B}$

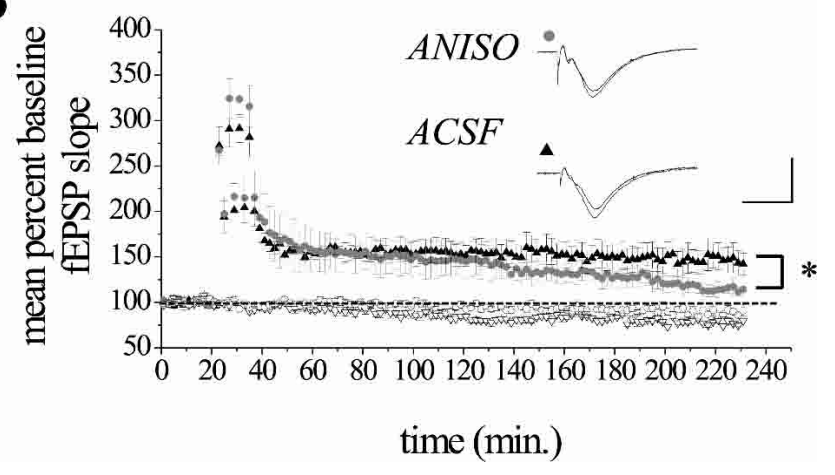

Figure 3 TA-CA1 synapses exhibit late-phase LTP that is sensitive to protein synthesis inhibition. The scale bar for all panels, $0.5 \mathrm{mV}, 20 \mathrm{msec}$ ( $A$ ) Representative example of a late-phase LTP experiment. The TA-CA1 synapses exhibited LTP that endured for at least $8 \mathrm{~h}$ following HFS. (B) Ensemble average of all late-phase LTP experiments conducted normal ACSF or in the presence of anisomycin. Late-phase LTP at TA-CA1 synapses was significantly inhibited by anisomycin treatment. Open circles and open triangles represent simultaneously recorded SC fEPSP in the presence and absence of anisomycin, respectively.

out tetanus) on TA synaptic transmission and found that anisomycin treatment did not result in a depression of synaptic transmission (mean percent of baseline at equivalent time inter$\mathrm{val}=109.4 \% \pm 6.9 \% ; n=4$ slices, from 3 rats). These results indicate that the TA-CA1 synapses can undergo a persistent synaptic enhancement that requires protein synthesis.

\section{DISCUSSION}

These data demonstrate that the direct projection from entorhinal cortex layer III undergoes both early- and late-phase LTP in adult rat hippocampal slices. Early LTP can be elicited by either of two different stimulation protocols, theta-burst or high-frequency stimulation. In contrast to previous studies (Colbert and Levy 1993), LTP can be elicited with inhibitory transmission intact. We suspect that differences in the slice-cutting procedure may account, at least in part, for the difference between our studies (Remondes and Schuman 2002) and previous studies (Colbert and Levy 1993). Specifically, because we cut slices with a vibratome (see Materials and Methods) with a blade-approach angle that spares more of the fibers that run along the longitudinal axis of the hippocampus, this approach may provide a better preservation of excitatory fibers, and therefore a more reliable axonal stimulation. In addition, others have shown that the cutting procedure affects the amount of inhibitory stimulation achieved in hippocampus slices (Lacaille and Schwartzkroin 1988).

It appears that the molecular mechanisms underlying TA-LTP induction by either TBS or HFS are similar: both require NMDA receptor activity (Remondes and Schuman 2002), voltagegated $\mathrm{Ca}^{2+}$ channels, and $\mathrm{GABA}_{\mathrm{B}}$-receptor-mediated inhibitory transmission. The latter requirement presumably reflects the need for $\mathrm{GABA}_{\mathrm{B}}$-receptor-mediated inhibition of GABA release (Davies et al. 1991). The fact that coapplication of both a GABA and $\mathrm{GABA}_{\mathrm{B}}$ antagonist no longer prevented LTP (Fig. 2B,D) supports this view (see Results). $\mathrm{GABA}_{\mathrm{A}}$ activation may be regulated by activation of presynaptic $\mathrm{GABA}_{\mathrm{B}}$ receptors that inhibit GABA release. If $G_{A B A}$ receptor activity is blocked, this would permit unrestricted GABA release, activation of postsynaptic $\mathrm{GABA}_{\mathrm{A}}$ receptors, and a block of LTP induction (Davies et al. 1991; Mott and Lewis 1992).

It is interesting to consider that some patterns of afferent activity may favor activation of the $\mathrm{GABA}_{\mathrm{B}}$ receptor system and thus enable information storage at these sites. In vivo, as opposed to the slice preparation, the full inhibitory interneuronal den- dritic and axonal trees are intact and fully active, likely making their contribution even more robust. Recent work shows that different classes of interneurons produce activity bursts at stereotyped positions in the hippocampal oscillatory structure (Klausberger et al. 2003). These data indicate that TA-LTP induction might be favored at certain temporal positions in hippocampal oscillations.

Protein synthesis-sensitive late-phase LTP, lasting as long as $10 \mathrm{~h}$, can also be elicited at the TA-CA1 synapses. Clearly, this pathway's capacity for long-term plasticity is critical if it participates in the encoding of learned behaviors. The long-lasting plasticity that we observe here, as well as its sensitivity to protein synthesis inhibition, could represent the capacity of the TA pathway to participate in the consolidation of memories, for example (Davis and Squire 1984). Given the remote distance of the TA synapses from their CA1 or entorhinal cortical cell bodies, the requirement for protein synthesis may reflect locally synthesized proteins (Aakalu et al. 2001).

Most studies have focused on the plasticity exhibited by the synapses that make up the trisynaptic pathway. Our findings show that the TA pathway also shows the capability for bidirectional plasticity, exhibiting both NMDA-receptor-dependent LTD (Dvorak-Carbone and Schuman 1999a) and LTP (Remondes and Schuman 2002). Many experimental and theoretical considerations have indicated that the TA pathway's primary function is to modulate information processed by the trisynaptic circuit. Metabolic labeling following learning tasks (Riedel et al. 1999; Sybirska et al. 2000) shows an intense rise in activity in SLM-the region of termination of the TA pathway-and raise the possibility that the TA pathway actually transmits the information required for some hippocampal-dependent behaviors. For example, lesion studies indicate that DG granule cells are not necessary for normal spatial learning as tested in a radial arm maze (Jarrard et al. 1984). Another study showed that the DG granule cells are necessary for normal spatial learning but not for the place selectivity of CA1 pyramidal cells (McNaughton et al. 1989). More recently, it has been shown that disrupting the transmission in the trisynaptic circuit (via CA3 lesions) preserves the place selectivity of CA1 pyramidal cells as well as the animal's recognition memory abilities (Brun et al. 2002). These findings raise the possibility that the TA pathway conveys most of the information necessary for place representations of CA1 neurons and some forms of spatial learning. Olga Vinogradova described the sensory tuning properties of the entorhinal cortical cells (Vinogradova and Bragin 1975), and hypothesized that the TA path- 
way could transmit complex sensory information to the hippocampus (Vinogradova 1984). Furthermore, the fact that CA1 pyramidal cells fire more bursts in the absence of dentate granule cells (McNaughton et al. 1989) has led to the proposition that the function of the trisynaptic circuit is to modulate CA1 activity, whereas the direct TA input to CA1 provides sensory information (McNaughton et al. 1989; Vinogradova 2001). Others have used anatomical and physiological data to propose a comparator role for the TA pathway (e.g., O'Keefe and Conway 1978). The results presented here are consistent with an independent encoding capacity of the TA circuitry. Together with previous data (Remondes and Schuman 2002), these data indicate that the anatomical and physiological organization of this circuitry renders it capable of discrimination and selection over SC-elicited activity and plasticity, thus creating a system capable of performing some of the operations needed for a comparator and/or match-mismatch device.

Lastly, the mechanisms of long-lasting plasticity documented here, and in particular the role of inhibition and protein synthesis, may instruct future considerations of the information storage capability of these synapses.

\section{MATERIALS AND METHODS}

\section{Slice Preparation}

Slices were prepared from 4-6-week-old male Sprague-Dawley rats. All animal usage was performed in accordance with the guidelines of the Caltech Institutional Animal Care and Use Committee. Specifically, after decapitation, the brain was removed rapidly to ice-cold artificial cerebrospinal fluid (ACSF). The dorsal surface of the posterior half of each hemisphere was glued on the stage of a cooled oscillating tissue slicer (OTS-300004; FHC) and covered with chilled ACSF; 450- and 500- $\mu \mathrm{m}$ slices were cut with a blade angle of $\sim 15^{\circ}$ relative to the long axis of the hippocampus, assessed visually for quality, and allowed to recover in an interface chamber at room temperature. Further dissection was performed in the recording chamber before the start of the experiment. Electrophysiology was done with the slices submerged and constantly perfused with oxygenated ACSF at room temperature. Clear isolation of the temporoammonic (TA) field response demanded further dissection of the slice as previously described (Colbert and Levy 1993; Dvorak-Carbone and Schuman 1999a), as well as clear separation of the TA and Schaffer-collateral pathways through field potential recordings (Fig. 1A). A differential sensitivity to baclofen ( $\mathrm{SC} \gg \mathrm{TA}$; Colbert and Levy 1992) was also noted, providing further evidence for separation of the two inputs.

\section{Electrophysiology}

Bipolar tungsten stimulating electrodes, FHC, were used (concentric, catalog \#CBBRC75 or paired needles catalog \#UEWMGGSELNNM) for stimulation. One was placed in stratum radiatum (SR) to stimulate the Schaffer collaterals, whereas the other was placed in the distal stratum lacunosum moleculare (SLM) to stimulate the TA pathway. Stimulus intensities ranged from 20-60 $\mu \mathrm{A}$ in the Schaffer collaterals and from 150-250 $\mu \mathrm{A}$ in the temporoammonic pathway, the stimulus duration was $100 \mu \mathrm{sec}$. The stimulation paradigms used were as follows: high-frequency stimulation (HFS), 4 tetani of $1 \mathrm{sec}$ each at a frequency of $100 \mathrm{~Hz}$ or theta burst stimulation (TBS), 10 bursts delivered at $5 \mathrm{~Hz}$ of 10 pulses at $100 \mathrm{~Hz}$ repeated twice, $30 \mathrm{sec}$ apart. Field recordings were made in current clamp mode with an Axoclamp 2B (Axon Instruments) using low-resistance microelectrodes filled with $3 \mathrm{M} \mathrm{NaCl}$. The drugs used were $40 \mu \mathrm{M}$ anisomycin (Sigma); $50 \mu \mathrm{M}$ APV (Sigma); $50 \mu \mathrm{M}$ nifedipine (Sigma); $20 \mu \mathrm{M}$ bicucculine (Sigma), and 1000 $\mu \mathrm{M}$ CGP 35348 (Tocris). This concentration was shown to consistently block $\mathrm{GABA}_{\mathrm{B}}$ currents and presynaptic $\mathrm{GABA}_{\mathrm{B}}$ receptors (Pham and Lacaille 1996); other currents-namely, NMDA-mediated excitatory postsynaptic currents-are not affected by it (Davies et al. 1991). All drugs were applied by dilution of stock solutions in the perfusion medium. The stock solutions were made up in water or DMSO.

\section{Data Acquisition and Analysis}

Data were collected on an IBM-compatible computer with inhouse software at a $10-\mathrm{kHz}$ sampling rate. In LTP experiments, potentiation was measured by measuring the initial slope of the field EPSP as a percentage of the initial baseline. Comparisons were made for data acquired $10 \mathrm{~min}$ before and $60 \mathrm{~min}$ after LTP induction or $10 \mathrm{~min}$ before and $3 \mathrm{~h}$ after the tetanus in late LTP experiments. All traces shown are averages of field EPSPs collected at the above time points. All of the data were plotted and analyzed using Origin. Student's paired $t$-tests were used to assess the statistical significance in all experiments. ANOVA followed by corrected multiple comparisons was used to compare the LTP results under several pharmacological conditions. The statistical significance was assigned to $p<0.05$.

\section{ACKNOWLEDGMENTS}

This work was supported by Fundacao para a Ciencia e Technologia (FCT)_Portugal and the Howard Hughes Medical Institute.

The publication costs of this article were defrayed in part by payment of page charges. This article must therefore be hereby marked "advertisement" in accordance with 18 USC section 1734 solely to indicate this fact.

\section{REFERENCES}

Aakalu, G., Smith, W.B., Nguyen, N., Jiang, C., and Schuman, E.M 2001. Dynamic visualization of local protein synthesis in hippocampal neurons. Neuron 30: 489-502.

Andersen, P., Gross, G.N., Lomo, T., and Sveen, O. 1969. Participation of inhibitory and excitatory interneurons in the control of hippocampal cortical output. UCLA Forum Med. Sci. 11: 415-465.

Andersen, P., Silfvenius, H., Sundberg, S.H., and Sveen, O. 1980. A comparison of distal and proximal dendritic synapses on CA1 pyramids in guinea-pig hippocampal slices in vitro. J. Physiol. 307: 273-299.

Brun, V.H., Otnass, M.K., Molden, S., Steffenach, H.-A., Witter, M.P., Moser, M.-B., and Moser, E.I. 2002. Place cells and place recognition maintained by direct entorhinal-hippocampal circuitry. Science 296: 2243-2246.

Cajal, S.R. 1968. The structure of Ammon's Horn (trans. L Kraft). CC Thomas, Springfield, MA.

Chapman, C.A., Perez, Y., and Lacaille, J.C. 1998. Effects of GABA inhibition on the expression of long-term potentiation in CA1 pyramidal cells are dependent on tetanization parameters. Hippocampus 8: 289-298.

Colbert, C.M. and Levy, W.B. 1992. Electrophysiological and pharmacological characterization of perforant path synapses in CA1: Mediation by glutamate receptors. J. Neurophysiol. 68: 1-8. . 1993. Long-term potentiation of perforant path synapses in hippocampal CA1 in vitro. Brain Res. 606: 87-91.

Collingridge, G. 1987. Synaptic plasticity. The role of NMDA receptors in learning and memory. Nature 330: 604-605.

Davies, C.H., Starkey, S.J., Pozza, M.F., and Collingridge, G.L. 1991. GABA autoreceptors regulate the induction of LTP. Nature 349: 609-611.

Davis, H.P. and Squire, L.R. 1984. Protein synthesis and memory: A review. Psychol. Bull. 96: 518-559.

Do, V.H., Martinez, C.O., Martinez Jr., J.L., and Derrick, B.E. 2002. Long-term potentiation in direct perforant path projections to the hippocampal CA3 region in vivo. J. Neurophysiol. 87: 669-678.

Doller, H.J. and Weight, F.F. 1982. Perforant pathway activation of hippocampal CA1 stratum pyramidale neurons: Electrophysiological evidence for a direct pathway. Brain Res. 237: 1-13.

. 1985. Perforant pathway-evoked long-term potentiation of CA1 neurons in the hippocampal slice preparation. Brain Res. 333: $305-310$.

Dvorak-Carbone, H. and Schuman, E.M. 1999a. Long-term depression of temporoammonic-CA1 hippocampal synaptic transmission. $J$. Neurophysiol. 81: 1036-1044.

. 1999b. Patterned activity in stratum lacunosum moleculare inhibits CA1 pyramidal neuron firing. J. Neurophysiol. 82: $3213-3222$.

Eichenbaum, H. 2000. A cortical-hippocampal system for declarative memory. Nat. Rev. Neurosci. 1: 41-50.

Empson, R.M. and Heinemann, U. 1995. The perforant path projection 
to hippocampal area CA1 in the rat hippocampal-entorhinal cortex combined slice. J. Physiol. 484: 707-720.

Frey, U. and Morris, R.G. 1997. Synaptic tagging and long-term potentiation. Nature 385: 533-536.

Frey, U., Krug, M., Reymann, K.G., and Matthies, H. 1988. Anisomycin an inhibitor of protein synthesis, blocks late phases of LTP phenomena in the hippocampal CA1 region in vitro. Brain Res. 452: $57-65$.

Friedman, H.R. and Goldman-Rakic, P.S. 1988. Activation of the hippocampus and dentate gyrus by working-memory: A 2-deoxyglucose study of behaving rhesus monkeys. J. Neurosci. 8: 4693-4706.

Golding, N.L., Staff, N.P., and Spruston, N. 2002. Dendritic spikes as a mechanism for cooperative long-term potentiation. Nature 418: $326-331$.

Hjorth-Simonsen, A. and Jeune, B. 1972. Origin and termination of the hippocampal perforant path in the rat studied by silver impregnation. J. Comp. Neurol. 144: 215-232.

Jarrard, L.E., Okaichi, H., Steward, O., and Goldschmidt, R.B. 1984. On the role of hippocampal connections in the performance of place and cue tasks: Comparisons with damage to hippocampus. Behav. Neurosci. 98: 946-954.

Kang, H., Welcher, A.A., Shelton, D., and Schuman, E.M. 1997. Neurotrophins and time: Different roles for TrkB signaling in hippocampal long-term potentiation. Neuron 19: 653-664.

Kauderer, B.S. and Kandel, E.R. 2000. Capture of a protein synthesis-dependent component of long-term depression. Proc. Natl. Acad. Sci. 97: 13342-13347.

Klausberger, T., Magill, P.J., Marton, L.F., Roberts, J.D., Cobden, P.M., Buzsaki, G., and Somogyi, P. 2003. Brain-state- and cell-type-specific firing of hippocampal interneurons in vivo. Nature 421: 844-848.

Lacaille, J.C. and Schwartzkroin, P.A. 1988. Stratum lacunosum-moleculare interneurons of hippocampal CA1 region. I. Intracellular response characteristics, synaptic responses, and morphology. J. Neurosci. 8: 1400-1410.

Leung, L.S., Roth, L., and Canning, K.J. 1995. Entorhinal inputs to hippocampal CA1 and dentate gyrus in the rat: A current-source-density study. J. Neurophysiol. 73: 2392-2403.

Lorente de No, R. 1934. Studies on the structure of the cerebral cortex. II. Continuation of the study of ammonic system. J. Psych. Neurol. 46: $113-177$.

McNaughton, B.L., Barnes, C.A., Meltzer, J., and Sutherland, R.J. 1989. Hippocampal granule cells are necessary for normal spatial learning but not for spatially-selective pyramidal cell discharge. Exp. Brain Res. 76: 485-496.

Mizumori, S.J., Barnes, C.A., and McNaughton, B.L. 1989. Reversible inactivation of the medial septum: Selective effects on the spontaneous unit activity of different hippocampal cell types. Brain Res. 500: 99-106.

Morris, R.G., Garrud, P., Rawlins, J.N., and O'Keefe, J. 1982. Place navigation impaired in rats with hippocampal lesions. Nature 297: 681-683.

Mott, D.D. and Lewis, D.V. 1992. GABAB receptors mediate disinhibition and facilitate long-term potentiation in the dentate gyrus. Epilepsy Res. Suppl. 7: 119-134.

Nguyen, P.V., Abel, T., and Kandel, E.R. 1994. Requirement of a critical period of transcription for induction of a late phase of LTP. Science 265: $1104-1107$.

O'Keefe, J. and Conway, D.H. 1978. Hippocampal place units in the freely moving rat: Why they fire where they fire. Exp. Brain Res. 31: $573-590$.

Otani, S. and Abraham, W.C. 1989. Inhibition of protein synthesis in the dentate gyrus, but not the entorhinal cortex, blocks maintenance of long-term potentiation in rats. Neurosci. Lett. 106: $175-180$.

Pham, T.M. and Lacaille, J.C. 1996. Multiple postsynaptic actions of GABA via GABAB receptors on CA1 pyramidal cells of rat hippocampal slices. J. Neurophysiol. 76: 69-80.

Remondes, M. and Schuman, E.M. 2002. Direct cortical input modulates plasticity and spiking in CA1 pyramidal neurons. Nature 416: $736-740$

Riedel, G., Micheau, J., Lam, A.G., Roloff, E., Martin, S.J., Bridge, H., Hoz, L., Poeschel, B., McCulloch, J., and Morris, R.G. 1999. Reversible neural inactivation reveals hippocampal participation in several memory processes. Nat. Neurosci. 2: 898-905.

Scoville, W.B. and Milner, B. 2000. Loss of recent memory after bilateral hippocampal lesions. 1957. J. Neuropsych. Clin. Neurosci. 12: $103-113$.

Squire, L.R. and Zola, S.M. 1997. Amnesia, memory and brain systems. Philos. Trans. R Soc. Lond. B Biol. Sci. 352: 1663-1673.

Stanton, P.K. and Sarvey, J.M. 1984. Blockade of long-term potentiation in rat hippocampal CA1 region by inhibitors of protein synthesis. $J$. Neurosci. 4: 3080-3088.

Steward, O. 1976. Topographic organization of the projections from the entorhinal area to the hippocampal formation of the rat. J. Comp. Neurol. 167: 285-314.

Steward, O. and Scoville, S.A. 1976. Cells of origin of entorhinal cortical afferents to the hippocampus and fascia dentata of the rat. J. Comp. Neurol. 169: 347-370.

Sybirska, E., Davachi, L., and Goldman-Rakic, P.S. 2000. Prominence of direct entorhinal-CA1 pathway activation in sensorimotor and cognitive tasks revealed by $2-\mathrm{DG}$ functional mapping in nonhuman primate. J. Neurosci. 20: 5827-5834.

Vinogradova, O.S. 1984. Current concepts of general properties and plastic phenomena in hippocampal neurons. Usp. Fiziol. Nauk. 15: $28-54$.

. 2001. Hippocampus as comparator: Role of the two input and two output systems of the hippocampus in selection and registration of information. Hippocampus 11: 578-598.

Vinogradova, O.S. and Bragin, A.G. 1975. Sensory characteristics of the cortical input of the hippocampus, the dentate fascia. Zh. Vyssh. Nerv. Deiat. Im IP Pavlova 25: 410-420.

Witter, M.P., Groenewegen, H.J., Lopes da Silva, F.H., and Lohman, A.H. 1989. Functional organization of the extrinsic and intrinsic circuitry of the parahippocampal region. Prog. Neurobiol. 33: 161-253.

Yeckel, M.F. and Berger, T.W. 1990. Feedforward excitation of the hippocampus by afferents from the entorhinal cortex: Redefinition of the role of the trisynaptic pathway. Proc. Natl. Acad. Sci. 87: $5832-5836$

Received January 23, 2003; accepted in revised form April 15, 2003. 


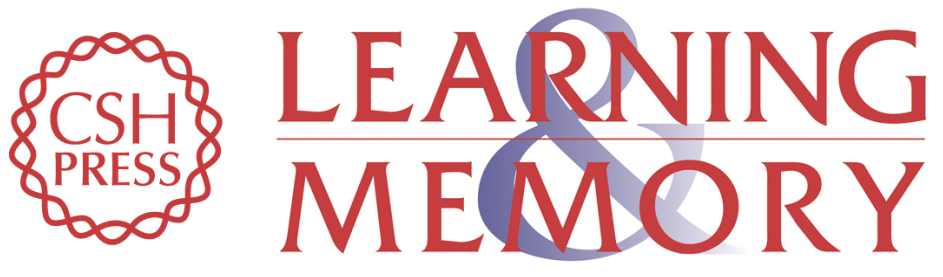

\section{Molecular Mechanisms Contributing to Long-Lasting Synaptic Plasticity at the Temporoammonic-CA1 Synapse}

Miguel Remondes and Erin M. Schuman

Learn. Mem. 2003, 10:

Access the most recent version at doi:10.1101//m.59103

References This article cites 50 articles, 8 of which can be accessed free at:

http://learnmem.cshlp.org/content/10/4/247.full.html\#ref-list-1

License

Email Alerting Receive free email alerts when new articles cite this article - sign up in the box at the Service top right corner of the article or click here. 